\title{
Cone rod dystrophy
}

INSERM

\section{Source}

INSERM. (1999). Orphanet: an online rare disease and orphan drug data base. Cone rod dystrophy. ORPHA:1872

Cone rod dystrophies (CRDs) are inherited retinal dystrophies that belong to the group of pigmentary retinopathies. 